\title{
LIVELIHOODS AND ENVIRONMENTAL CHALLENGES IN COASTAL COMMUNITIES OF NIGERIA
}

\section{Akinwale $\mathrm{AA}^{1^{*}}$}

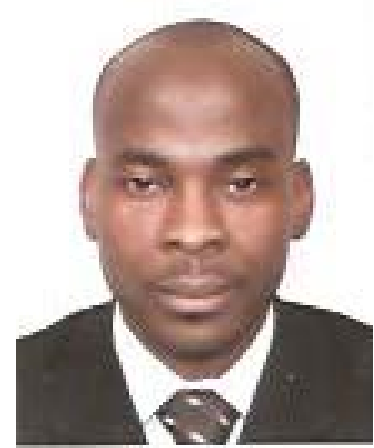

Akeem Ayofe Akinwale

Corresponding author email: akimascholar@yahoo.com

${ }^{1}$ Department of Sociology, Landmark University, Omu Aran, Kwara State, Nigeria 


\section{ABSTRACT}

Several socio-economic activities such as construction, farming, gas flaring, oil exploration and transportation have affected the physical environment in Nigeria. These activities constitute major sources of revenue for the majority of Nigerians. Yet, there is disconnection between adverse consequences of the above-mentioned socio-economic activities and the need to protect the environment. Though Nigerian governments have established environmental protection agencies, environmental challenges remain high in Nigeria. This situation can be adduced to several years of neglect and poor socio-economic conditions in Nigeria where people largely contravene environmental laws with impunity in their struggle for survival. How do socio-economic activities influence the coastal environment in Nigeria? What are local contributions to environmental protection in Nigeria? These questions were addressed within interpretive theories complemented by 32 Focus Group Discussions among youth and community leaders in eight coastal communities in Lagos State of Nigeria. Respondents were purposively selected from the coastal communities in Lagos State, Nigeria. Results showed a consensus on the dilemma in socio-economic activities of coastal communities with minor variations. Fishing, farming, sand digging and trading were popular occupations in the study areas. Dissenting views were expressed concerning implications of socio-economic activities on the coastal environment. Fishermen claimed that sand digging created hindrances to fishing activities, while sand diggers complained about pollution associated with chemicals found on the water. Farmers confessed that they practised bush burning which could adversely affect the environment. However, awareness of environmental laws was generally low. This finding indicates that law enforcement mechanisms for the implementation of environmental laws are weak in Nigeria. Beyond the activities of the environmental protection agencies established by the Nigerian governments, local measures for environmental protection include temporary withdrawal from aquatic environment and sanction of defaulters. The study concludes that with contamination of natural resources coastal livelihoods have become persistently deplorable. Therefore, combined efforts are essential for controlling environmental challenges in coastal communities.

Key words: Biodiversity, coast, degradation, environment, livelihoods 


\section{INTRODUCTION}

The battle between people and environment dates from antiquity. It has taken different dimensions with increasing environmental challenges arising from human struggle for survival. Concerns about environmental challenges such as acid rain, ozone depletion and climate change became prominent in the 1950s. Decades of environmental movements have resulted in higher awareness of environmental issues. The United Nations (UN) assembled 113 government representatives from different countries at Stockholm in 1972 for environmental protection [1]. Consequently, the UN Environmental Protection was established [2, 3].

The 1980s environmental concerns (ozone depletion, climate change and biodiversity loss) led to renewed interests in the understanding of how human activities transformed the environment. It was argued that chemicals utilisation damaged the stratospheric ozone layers, fuels burning released green house gases that caused global warming and conversion of ecosystems reduced biodiversity. Expanding the concerns for environmental issues beyond state actors, the 1992 Rio Conference focused on climate change, biodiversity protection, and sustainable development. Both state and non state actors participated actively in the Rio conference.

With increasing emphases on development, recognition of the importance of environmental management was unprecedented [4]. This recognition was reinforced by the belief that people derive their capacities from nature and society [5]. It was argued that without land, water, labour, capital or other natural resources people would produce nothing [6]. Similar studies on land and deadly environmental issues are numerous [7-14]. However, effects of land use practices and community interaction with the coastal environment have been understudied in developing countries [1]. This study is an attempt to fill the lacuna. In most developing countries including Nigeria, land surface is largely used for agriculture, grazing and other human activities. Unfortunately, land has become less productive despite increasing demands for high-quality food [8]. This has been adduced to degradation arising from unregulated human socio-economic activities [2]. Environmental disasters can be linked with human quest for survival. The situation in coastal environment is worse. Globally, people have consumed more than half of the total renewable supplies of fresh water and demands for water remain high [8]. Water tables have rapidly dropped in densely populated regions where agriculture accounts for about $90 \%$ of the total human water consumption. As such, about 3.5 billion people will experience acute water shortages by 2025 [8]. A significant number of the projected population can be located in Nigeria, a highly heterogeneous and the most populous African country.

Nigeria has three main environmental regions: savanna, tropical forests, and coastal wetlands. These environmental regions greatly affect the cultures of the people who live there. The dry, open grasslands of the savanna make cereal farming and herding a way of life for the Hausa- Fulani [15]. The wet tropical forests in the south provide opportunities of planting different crops and income generation for the Yoruba, Igbo, and other ethnic groups. The ethnic groups such as the Ijaw and the Kalabari living along the coast are forced to keep their communities small due to lack of dry land.

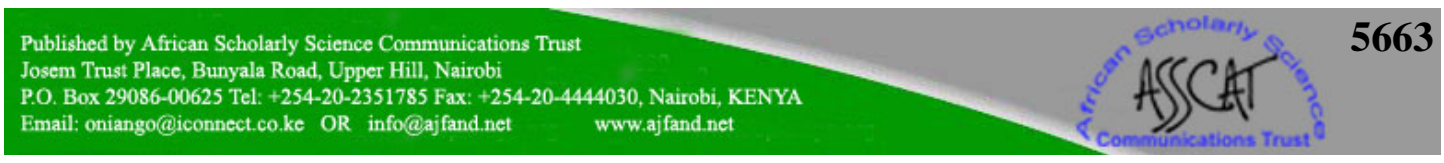


Living among creeks, lagoons, and salt marshes makes fishing and the salt trade part of everyday life in the area. The mangrove forest extends along the coast of the southern Nigeria and accommodates freshwater plants such as raffia palm, a raw material for the production of a local gin. The Niger and Benue Rivers unite at the centre of Nigeria and split the country into three separate sections representing boundaries of the three major ethnic groups, with the Hausa in the north, the Yoruba in the southwest, and the Igbo in the southeast [15]. These ethics groups are familiar with different vegetation zones such as the tropical rainforest, the savannah region and the mangrove forest.

Accumulated knowledge on environmental issue shows that land access and land rights relate significantly to livelihood security [16]. This reality provides justification for the Nigerian environmental legislation including the Environmental Sanitation Law, the Environmental Protection Agency Act, the Petroleum Act and the Environmental Impact Assessment Act. The latest environmental law is contained in Section 20 of the 1999 Nigerian Constitution, which empowers the state to protect and improve the environment and safeguard the water, the air, the land, the forest and wildlife of Nigeria [17]. However, public awareness of these environmental laws remains relatively low due to lack of effective law enforcement mechanisms. Unfortunately, poor environmental awareness on how best to manage the Nigerian economically viable but fragile environment has resulted in incessant pollution and degradation [2]. Thus, this study examines livelihoods and environmental challenges in coastal communities of Nigeria. The article has been organised into different sections starting from introduction followed by the concept of livelihood, livelihood framework, methodology, results and conclusion.

\section{THE CONCEPT OF LIVELIHOOD}

Livelihood is a process by which people make a living through specific capabilities, assets, and activities [18, 19, 20]. Earlier anthropological study showed that livelihood extends beyond basic life necessities to include information sharing, social relationships management and identity maintenance [21]. Obviously, with an overlap of different layers of social life based on resources and their utilisation livelihood is a holistic phenomenon. Essentially, the discourse on livelihood cannot be disconnected from an understanding of environmental and socio-cultural contexts of society. Environmental factors including rainfall with other natural resources and sociocultural factors such as economy, politics and kinship networks can affect livelihood. These factors influence the extent to which people manage or mismanage the environment. Uncontrolled extraction of resources has led to mismanagement of resources and depletion of valuable biodiversity, which encompasses all species of plants, animals, micro organisms and their ecosystems and ecological processes [7].

Over-exploitation of fisheries resources followed by agriculture, transport sources, and poorly planned and managed coastal developments have led to rapid degradation of vulnerable coastal and offshore habitats [22]. In contrast, depletion of biodiversity has aided climate change, which threatens human survival [23]. Climate change through extreme temperature, frequent flooding and drought and increased salinity of

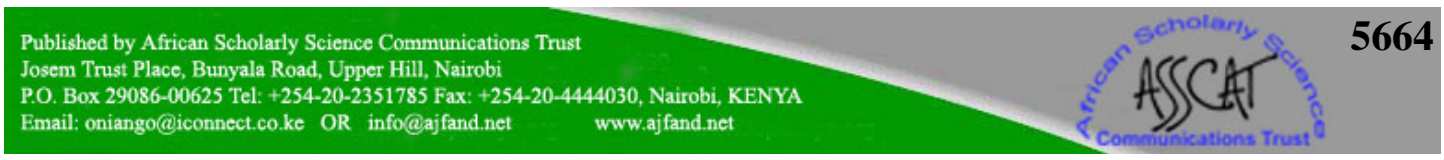


water used for irrigation has become a recurrent environmental problem in Nigeria. Though climate change is a threat to agricultural and non-agricultural socioeconomic development, agricultural production activities are generally more vulnerable to climate change than other sectors [23]. The sector is also the source of raw materials used in the processing industries as well as a source of foreign exchange earnings for the country. How much one can hold climate responsible for changes in agricultural productivity in Nigeria will, for a long time, remain a subject of research as long as other factors are at interplay in determining agricultural productivity. In contrast, agricultural activities also contribute to climate change. Thus, the corresponding interaction between agricultural activities and climate change requires further research.

It has been discovered that the poor degrade the environment in various ways, while the environment takes a particularly devastating toll on the poor through disasters [14]. Some scholars similarly showed that overexploitation of natural resources and depletion of the biodiversity was a key source of poverty [7]. In this context, landscape structuration perspective is useful for comprehending community-specific trajectories of positive and negative interaction with the coastal environment [24]. This perspective provides insights into how livelihoods intersect with social and ecological dynamics.

The question remains, therefore, as to whether the production level will ever meet the demand level given the rate of population growth in Nigeria [23]. The impact of climate change usually depends on a range of the climate parameters' changes and on the country's social, cultural, geographical and economic backgrounds. In Nigeria, the location and size of, and the characteristics of the relief give rise to various types of climates ranging from tropical rainforest along the coasts to savannah climate in the northern parts of the country. The inter-annual variability of rainfall, particularly in the northern parts is large, often results in climate hazards, especially floods and droughts with their devastating effects on food production and associated calamities and human sufferings.

From a water balance perspective, the country experiences large spatial and temporal variations in rainfall, and less variation in evaporation and evapo-transpiration. It has been shown that any change in climate is bound to impact on the agricultural sector in particular and other socio-economic activities in general. Climate change could have both positive and negative impacts. The impacts could be measured in terms of effects on crop growth, availability of soil water, soil fertility, soil erosion, incidents of pests and diseases, and sea level rise, which also influence the yield of crops amidst other factors such as fertilizer, cultural practices, and managerial abilities of the farmers [23]. The melting snows of Kilimanjaro provide dramatic evidence that climate change has been affecting the environment with dire consequences on livelihoods especially in agrarian societies [9].

In Nigeria, over 20 million people live along the coastal zone. Meteorological data have shown that rainfall pattern in Nigeria has changed in the past decades due to an abrupt change in climate [12]. It has been predicted that climate change will create

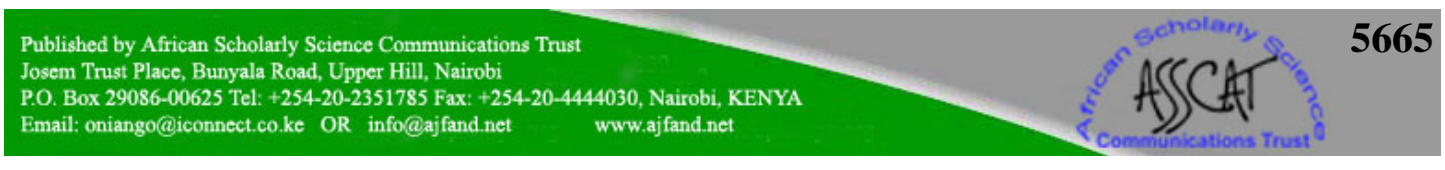




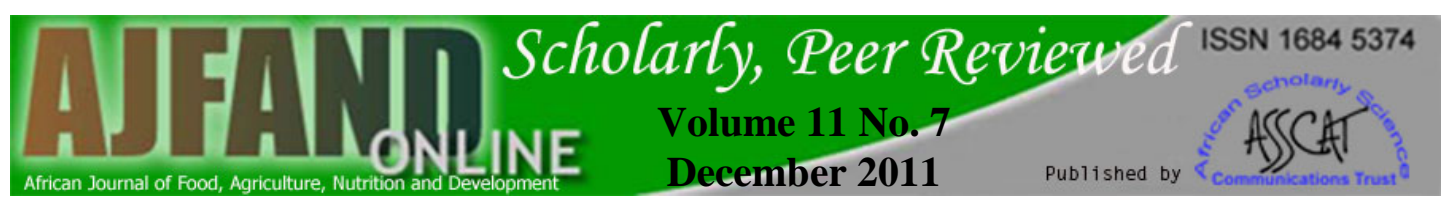

uncertainty in the rainfall pattern and pose serious threat to food security. In light of the above, the study of livelihood is essential for an understanding of peopleenvironment interaction and its implications for poverty alleviation. Situations in which some people live in poverty and some live in prosperity can be linked to political economy of environmental differences. Normally, people in resources endowed environments will be more prosperous than their counterparts in disadvantaged areas. This model does not fit the Nigerian paradox of poverty in the midst of plenty resources. People in disadvantaged areas seem to be at higher advantage than their counterparts in resources endowed environment in Nigeria. A livelihood framework provides insights to this discourse.

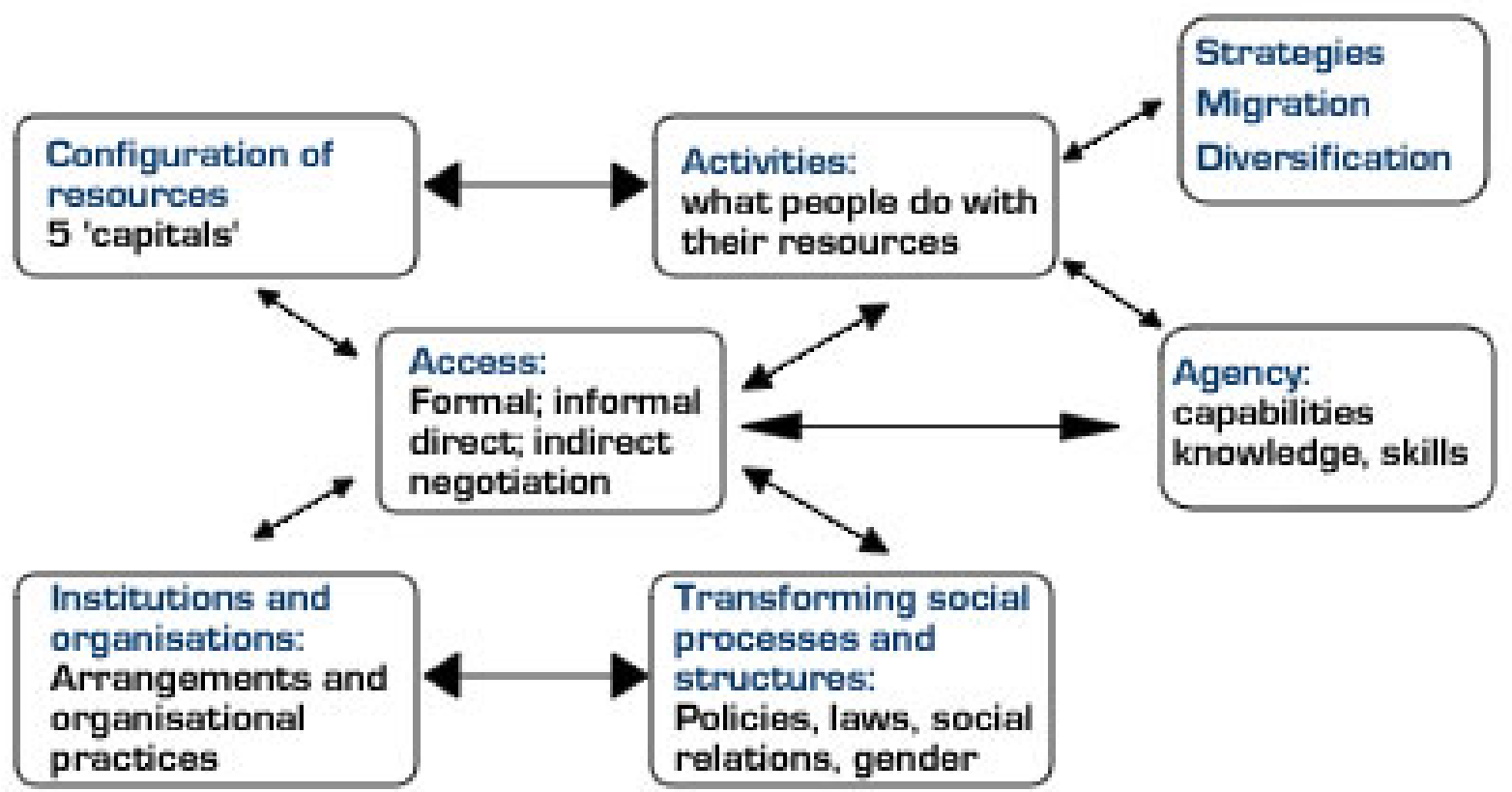

\section{Unit of Analysis: Individuals, social groups, networks, households?}

\section{Context: \\ Seasonality, trends, shocks global-local level; the external environment}

Figure 1: Livelihood Framework [18]

The livelihood framework in Figure 1 focuses on resource base and people's capacities to act within specific social, economic, political, ecological and cultural contexts. It starts with an analysis of local resources and skills available for constructing livelihood activities. The canons of the framework include people's strengths and potentials which may lie in social networks. This framework shows that livelihoods can largely be understood in the process of scanning local knowledge within locally specific contexts where they occur. Therefore, an understanding of livelihood analysis with the interplay of different processes operating at different 


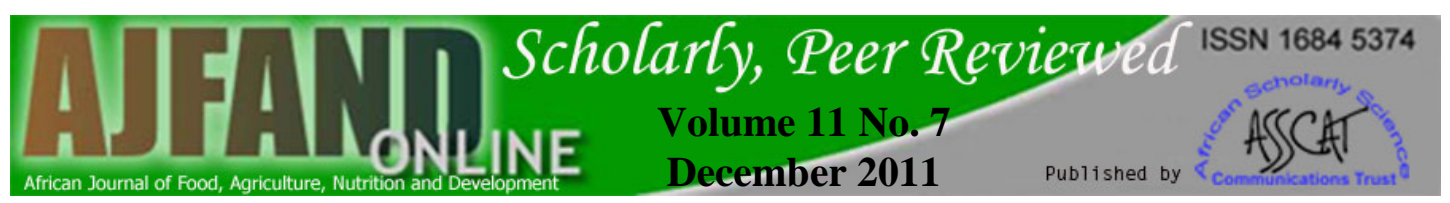

levels is essential. Livelihoods analysis stems from mapping out different resources at people's disposal. These resources include tangible assets such as land and properties as well as non-tangible assets such as law and policies. It is important to note that these resources are socially constructed. Thus, people's negotiation for and utilisation of resources is a product of local and global processes in construction of social reality. This assumption and the beliefs that local capacities and voices should be brought forward in research and development planning gained popularity in the 1980s especially through the adoption of participatory approaches in rural development [25]. This line of thinking is impregnated by gradual shift in social change paradigm from the primacy of centralized development planning to increasing emphasis on people's own activities. It is in this context that democratisation of rural development practice and power of people's agency can be understood. Agency implies capacity to manage thought processes, regulate behaviour and produce changes through actions. Ability to navigate within social networks is a component of livelihood.

\section{METHODOLOGY}

The study was guided by two research questions: How do socio-economic activities influence the coastal environment? What is the extent of community participation in environmental protection? The questions were addressed through both primary and secondary data. The primary data were generated from 32 focus group discussions (FGD) conducted among youth and adults in eight coastal communities purposively selected from the existing coastal communities in Lagos State. The participants were purposively selected based on gender, age, status in the communities and availability. Table 1 shows a list of selected coastal communities and participants in Lagos State.

The entire study was driven by strict adherence to ethical principles in social science research. Each FGD comprised 5-8 participants. Four FGD were conducted in each community and participants were children and youth, adults and community leaders. Each FGD was homogeneous in terms of gender and age group. The total sample of the participants from all the selected coastal communities was 211 as shown in Table 1. The participants comprised male and female youth aged 15-34 years while adults and community leaders aged 35 years and above were considered. Stratified and purposive sampling techniques were adopted, indicating a selection of eligible participants from different segments of the population in each coastal community. The 20 Local Government Areas (LGAs) of Lagos State was grouped into coastal and non coastal areas. Subsequently, four LGAs and eight coastal communities were purposively selected to represent the coastal areas. In each selected community, households were visited and eligible participants were purposively selected. An FGD guide was designed to explore participants' opinions and perceptions about livelihoods and environmental challenges in their communities. Each FGD comprised same sex persons to protect participants from unnecessary constraints.

The analysis of the above mentioned FGDs was conducted through a combination of different models of content analysis, that is, a systematic coding and categorization of textual information in order to ascertain the trends and patterns of words used, their

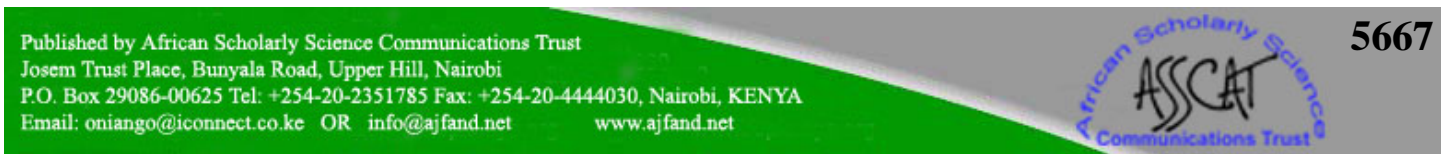




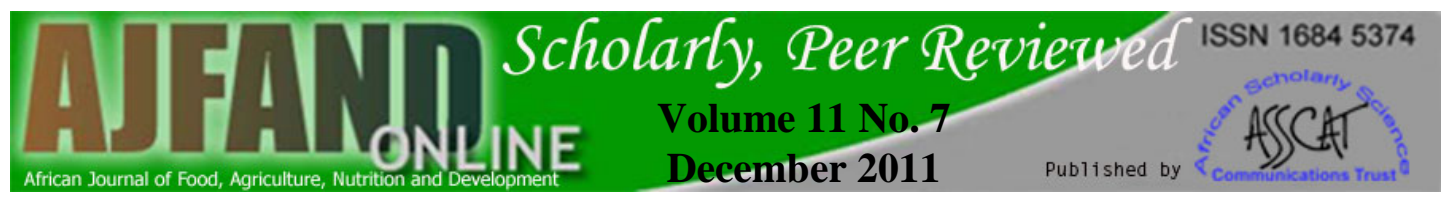

frequency, their relationships and the structures and discourses of communication [26].

\section{RESULTS}

The study results are presented below in accordance with research questions. Fundamental issues raised and discussed in the livelihood framework provide a basis for an understanding of the results obtained from 32 FGDs in selected coastal communities of Lagos State where people have collectively contributed to environmental degradation on the one hand and its protection on the other. While people in the coastal communities endanger the natural environment in the course of their livelihoods, the environment has also accommodated hazards, thereby reducing human livelihood opportunities. The coastal environment remains influential despite human attempts to subdue it.

\section{Socio-Economic Activities in the Coastal Environment}

Multiple socio-economic activities were discovered in the coastal communities. The activities can be grouped into two categories (major activities and minor activities) depending on participants' perceived level of involvement. Fishing, fish processing, farming, water transportation service, sand digging and trading were predominant occupations followed by other activities including hunting, domestic animal husbandry, craft and ethno-medicine. Two-third of the participants combined different occupations to enhance living standards. There was a general agreement amongst the participants that they relied on exploitation of land, water and forest resources. For instance, participants in one of the focus group discussions reached the following consensus:

Every member of this community is involved in one economic activity and another. Even children are not left alone. In those areas where the parents need help, young boys and young girls are called for assistance. When you see children in the lagoon they are either playing or working. Young boys can paddle canoe and use it to carry passengers, crossing from one village to another. Both men and women could be seen working on the farm. Women have their own farm and men have their own farms. But, majority of those that engaged in fishing are men. Women also have their own area of specialization in which men cannot compete with them. That area is trading. Our women go to market for buying and selling. Please don't forget our youths. They go to school but before then and during holidays they help their parents on the farm, while some paddle canoe to carry passengers. Some are good at fishing. The female youths take after their mothers. (Female Adult FGD, Lagos, July 2008)

While men largely concentrated in physical activities that affect the coastal environment majority of the women specialised in trading, craft and home based 


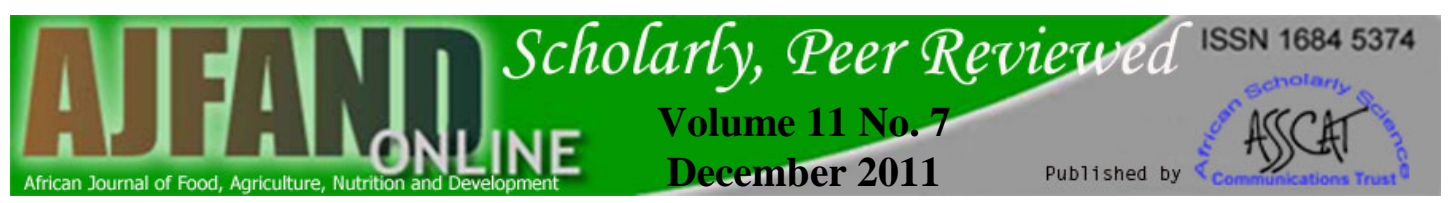

economic activities. Participants expressed different views concerning how they manipulated the coastal environment in attempts to gratify life supporting needs such as food, clothing, shelter and income. About their dexterity in managing the aquatic environment, male youth who specialised in fishing and water transportation service were more vocal followed by sand diggers who claimed to posses extra-ordinary skills needed for staying inside the lagoon for several minutes before digging out sand. This finding resonates with the scholarly assumption that livelihood extends beyond household resources and activities geared towards survival to include security against unexpected shocks and crises [27].

\section{Environmental Challenges in the Coastal Communities}

Environmental challenges in the coastal communities were diverse. They ranged from flooding and coastal erosion to soil infertility, deforestation and pollution. Flooding and erosion threaten lives and properties by destroying top soil and making roads impassable. The severity of both water and air pollution was described. A significant number of participants (52.0\%) complained of exposure to heat and smoke during fish processing mostly done by women. Almost all male adult discussants observed that women had contributed more to environmental degradation in the coastal environments. There was an agreement among members of a male adult FGD that:

\section{Women are more likely to engage in activities that constitute dangers to natural environment in our communities. They go to the bush to fetch wood for cooking and when they are cooking, there is smoke everywhere. They do this daily in the process of cooking or smoking fish. I agree that men also engage in bush burning. But men do not put fire in the bush anyhow. They only do that occasionally when they are preparing for planting. (Male Adult FGD, Lagos, July 2008)}

Significant proportions of men and women displayed understanding of local sources of environmental challenges in the coastal environment. While men occasionally indulge in bush burning or use chemicals to catch fish women fetch and burn firewood for fish processing or domestic cooking. In line with the 1994 World Resources Institute report, firewood and brush provide about 52 percent of the domestic energy supply in sub-Saharan Africa. However, the above activities are agricultural practices that are detrimental to the environment. They can aggravate the depleted ozone layers. Fishermen claimed that those engaging in sand digging have created hindrances to fishing activities, while those engaged in sand digging accused fishermen of polluting the water with chemicals and all sorts of substances in attempts to force fish out of their hidden places. Many farmers remained neutral in the discourse of implications of economic activities on coastal environment though few of them confessed that they practised bush burning which could adversely affect the environment. Activities such as sand digging and excessive fishing affect the coastal environment negatively as they have contributed to local and global environmental degradation. The following remark is a consensus reached in one of the FGDs.

It is difficult for the people who do sand digging and fishing to work together. We that do fishing, if we see that they have started digging 


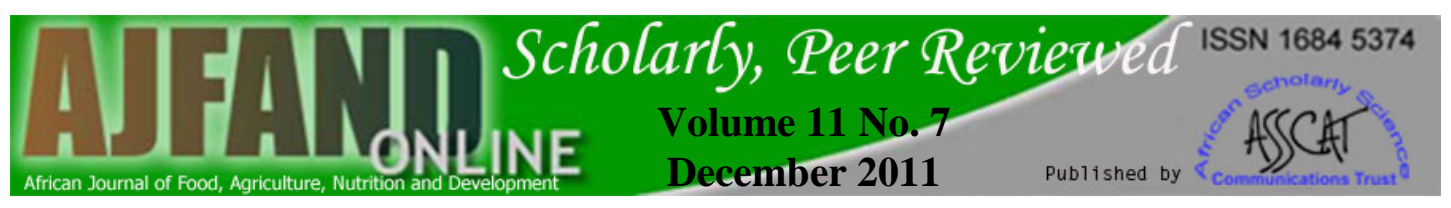

sand somewhere we always go to another location to search for fish because sand digging would make water to be rough and many fish would have run away and not come back until the water becomes clear. (Male Youth FGD, Lagos, July 2008)

Participants recognised the power of climate change in the discourse of socioeconomic crises that threatened their livelihoods. They, however, attributed delay of the rain to unknown forces and divine providence. This throws up the question of traditional belief system in the understanding of environmental challenges. This understanding extends beyond earlier reports that pollution and deforestation increased temperature and delayed the rain [28]. The question of African mythology, which influences behavioural intervention in problem diagnosis and its solution cannot be taken for granted without serious setbacks.

\section{Community Participation in Environmental Protection}

Participants were conscious of local causes of environmental problems but expressed concerns over their inability to afford facilities that would enhance survival without exhausting resources in the environment. Generally, fishing, farming and sand digging were the predominant activities in the coastal communities with men overwhelming concentration. Women largely engaged in trading and fish processing, which requires firewood.

We do not find things easy in our community and coping with
environmental challenges is not easy because the government does
not remember us in anything. Our parents continue to stress
themselves to ensure that everything is fine with us. But often the
biggest source of environmental challenges is change in weather
conditions. In this case, our people are good at praying. They always
pray that God should bring rain on time. If rain falls they also pray
that the rain should not be too much and that it should not bring
thunder, which can remove the roof of our house. (Female Youth
FGD, Lagos, July 2008)

Other participants lamented over hindrances to survival and complained that lack of electricity and modern equipments had created setbacks in community efforts to ensure environmental protection. However, peoples' awareness of government policy on environmental protection was generally low. Few discussants perceived their economic activities as dangerous to the aquatic environment. The commonly mentioned problems were inadequate fishing equipments, hindrances to successful fishing, idleness, poverty and inadequate food. It was disclosed that local measures for environmental protection included temporary withdrawal from fishing and sand digging during certain period and community actions against anybody caught using chemicals to catch fish. 


\section{CONCLUSION}

In light of this study, the role of local communities in framing the risks of and solutions to coastal environmental challenges is significant within strong interaction of socio-economic activities and the coastal environment. However, participants' narratives indicated that environmental influence was stronger than livelihoods, which became persistently deplorable. The downturns in livelihoods can be blamed on community contamination of natural resources and noncompliance with environmental laws. This infraction may aggravate the global socio-environmental malaise. Therefore, concerted community efforts are needed to provide leadership and modalities for controlling the environmental challenges in coastal communities. Fundamentally, state interventions should be geared towards improving the deplorable livelihoods in coastal communities with provision for training in alternative sources of revenue. Provision of modern equipments that can enhance coastal socio-economic activities will reduce the volumes of environmental challenges. In this regard, rural electrification and technological training are essential and should be provided. Essentially, good governance is central to livelihoods and environmental quality improvement. Therefore, local governments' responsibilities should include provision of adequate social welfare services for coastal communities.

Table 1: List of Selected Coastal Communities and Participants in Lagos State

\begin{tabular}{|l|c|c|c|c|c|}
\hline \multirow{3}{*}{$\begin{array}{l}\text { Coastal } \\
\text { Community }\end{array}$} & \multicolumn{4}{|c|}{ Participants in Focus Group Discussions (FGDs) } \\
\cline { 2 - 5 } & $\begin{array}{c}\text { Adults and Community } \\
\text { Leaders }\end{array}$ & \multicolumn{2}{c|}{ Children and Youths } & $\begin{array}{c}\text { All } \\
\text { FGDs } \\
\end{array}$ \\
\cline { 2 - 5 } & $\begin{array}{c}\text { Female FGDs } \\
\text { (N=8) }\end{array}$ & $\begin{array}{c}\text { Male } \\
\text { FGDs } \\
\text { (N=8) }\end{array}$ & $\begin{array}{c}\text { Female FGDs } \\
\text { (N=8) }\end{array}$ & $\begin{array}{c}\text { Male FGDs } \\
\text { (N=8) }\end{array}$ & \\
& & & & & \\
\hline Agbowa & 6 & 5 & 8 & 5 & 24 \\
Ebute Ero & 5 & 6 & 5 & 6 & 22 \\
Ebute Metta & 7 & 8 & 8 & 7 & 30 \\
Etegbin & 8 & 7 & 6 & 7 & 28 \\
Ibeju & 5 & 7 & 5 & 6 & 23 \\
Irewe & 7 & 8 & 8 & 8 & 31 \\
Makoko & 6 & 5 & 8 & 7 & 26 \\
Sibiri & 8 & 7 & 6 & 52 & $\mathbf{2 1 1}$ \\
\hline Total & $\mathbf{5 2}$ & $\mathbf{5 3}$ & $\mathbf{5 4}$ & & \\
\hline
\end{tabular}

Source: 2008 Fieldwork on Livelihoods and Environmental Challenges in Coastal Communities 


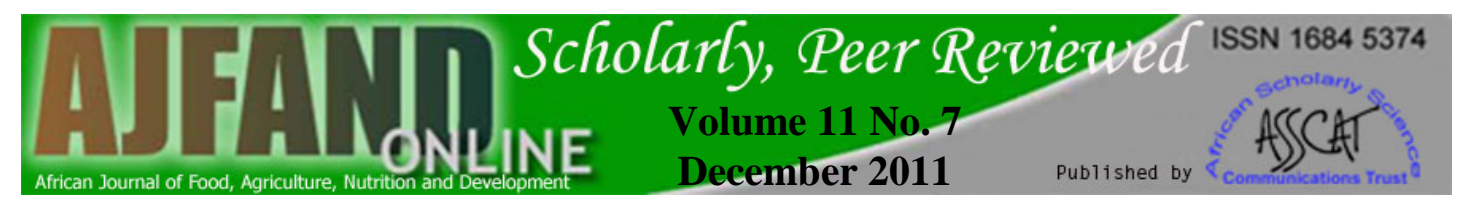

\section{REFERENCES}

1. Liverman DM Geography and the Global Environment. Annals of the Association of American Geographers 1999; 89 (1): 107-20.

2. Dosunmu S IMO's Response to Current Environmental Challenges 2007. http://www.sunnewsonline.com/webpages/features/enterprise/2007/oct/20/ente rprise-20-10-2007-002.htm. Accessed in March 28, 2008.

3. Caldwell LK International Environmental Policy: From the Twentieth to the Twenty-First Century. Durham Duke University Press; 1996.

4. Murray B "Environmental Issues and Challenges". Paper presented at the world economic forum business summit, China. April 19; 2002.

5. Haugaard M Reflections on Seven Ways of Creating Power. European Journal of Social Theory 2003; 6 (1): 87-133.

6. Shipton $\mathbf{P}$ Land and Culture in Tropical Africa: Soils, Symbols, and the Metaphysics of the Mundane. Annual Review of Anthropology 1994; 23: 34777.

7. Agbogidi OM and AU Ofuoku. Biodiversity Conservation and Poverty Alleviation in the Niger Delta Area of Nigeria. Agriculturae Conspectus Scientificus 2006; 71 (3): 103-10.

8. Raven PH "The Environmental Challenge". Paper presented at the natural history museum London, England. May 22; 2003.

9. McCarthy J and M McKenna How Earth's Ice is Changing. Environment 2000; December: 8-18.

10. World Bank. World Development Report 2000/2001: Attacking poverty. New York Oxford University Press, 2000.

11. Cline-Cole RA African and Africanist Biodiversity Research in a Neo-liberal Context. Journal of the International African Institute 1996; 66 (1): 145-58.

12. Oladipo EO An Indication of Abrupt Change of Rainfall and Its Potential Impact on Energy Development in Nigeria. In: JC Umolu (Ed). Global Climate Change: Impact on Energy Development. Nigeria Damtech Nigeria Limited. 1995: 30-42.

13. Bebbington A Modernization from Below: An Alternative Indigenous Development? Economic Geography 1993; 69 (3): 274-92.

14. Kates RW and $\mathbf{V}$ Haarmann Where the Poor Live: Are the Assumptions Correct? Environment (1992); 4 (11): 25-8. 
15. Fabusoro E, Matsumoto T and $\mathbf{M}$ Taeb Land Rights Regimes in Southwest Nigeria: Implications for Land Access and Livelihoods Security of Settled Fulani and Pastoralists. Land Degradation and Development 2007; 19 (1): 91103.

16. Nhamo $\mathbf{G}$ and $\mathbf{E}$ Inyang Framework and Tools for Environmental Management in Africa. Dakar CODESRIA, 2011.

17. Makinde $\mathbf{O}$ and $\mathbf{T}$ Adegoke Environmental Policy and Its Enforcement in Nigeria. Lagos Organisation Review 2008; 5 (10): 159-69.

18. Ellis F Rural Livelihoods and Diversity in Developing Countries. Oxford University Press, 2000.

19. Carney D Sustainable Rural Livelihoods: What Contributions Can We Make? London Department for International Development, 1998.

20. Chambers R and G Conway Sustainable Rural Livelihoods: Practical Concepts for the 21st Century. Brighton Institute of Development Studies, 1992.

21. Wallman S Eight London Households. London Tavistock, 1984.

22. Churcher $\mathbf{C}$ "Linking National and Regional Efforts in Ocean and Coastal Management: African Perspectives”. Keynote address presented at the 3rd global conference on oceans, coasts and islands, Accra, Ghana, Jan 27-28, 2006.

23. Ajetomobi $\mathbf{J}$ and A Abiodun Climate Change Impacts on Cowpea Productivity in Nigeria. African Journal of Food Agriculture Nutrition and Development 2010; 10 (3): 2258-2271.

24. Appendini K and DM Liverman Agricultural Policy and Climate Change in Mexico. Food Policy 1994; 19: 149-64.

25. Long $\mathbf{N}$ Rural Development Sociology: Actor Perspectives. London Routledge, 2002.

26. Grbich C Qualitative data analysis: An introduction. London Sage, 2007.

27. Olujide MG "Third Economy for Sustainable Livelihoods: Women as Key Actresses". Paper presented at the Nigerian Environmental Study/Action Team (NEST) workshop on third economy, Ibadan, Nigeria, Jan. 24, 2000.

28. Leach $\mathbf{M}$ and $\mathbf{J}$ Fairhead Challenging Neo-Malthusian Deforestation Analyses in West Africa's Dynamic Forest Landscapes. Population \& Development Review 2000; 26 (1): 17-43. 